\title{
Low-level laser on femoral growth plate in rats ${ }^{1}$
}

\author{
Laser terapêutico de baixa potência na placa de crescimento de ratos
}

\author{
Sidney Piesco de Oliveira ${ }^{\mathrm{I}}$, Sheila Canevese Rahal ${ }^{\mathrm{II}}$, Elenize Jamas Pereira ${ }^{\mathrm{III}}$, Paulo Ricardo de Oliveira Bersano ${ }^{\mathrm{IV}}$, Fabio de \\ Almeida Vieirav, Carlos Roberto Padovani ${ }^{\mathrm{VI}}$
}

IMaster, Department of Veterinary Surgery and Anesthesiology, School of Veterinary Medicine and Animal Science, UNESP, Botucatu-SP, Brazil. Intellectual and scientific content of the study, manuscript writing, involved with technical procedures and in the protocol.

IIPhD, Full Professor, Department of Veterinary Surgery and Anesthesiology, School of Veterinary Medicine and Animal Science, UNESP, BotucatuSP, Brazil. Mentor, conception and design of the study, manuscript writing, critical revision.

IIIPhD, Associate Professor, Department of Medical Clinic, School of Medicine, UNESP, Botucatu-SP, Brazil. Acquisition of data, helped with technical procedures.

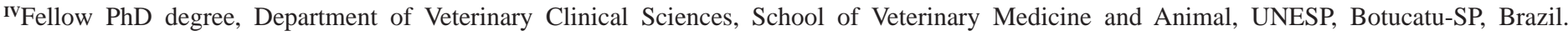
Pathological and histometric examinations.

vVolunteer Faculty, Dog Bakery Institute, Sao Paulo-SP, Brazil. Helped with technical procedures.

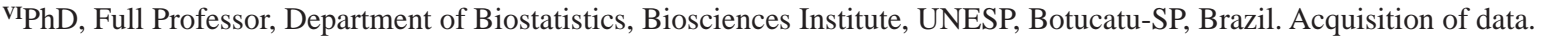

\begin{abstract}
PURPOSE: To determine the influence of low-level laser therapy on femoral growth plate in rats.

METHODS: Thirty male Wistar rats aged 40 days were divided into two groups, G1 and G2. In G1 the area of the distal growth plate of the right femur was irradiated at one point using GaAlAs laser $830 \mathrm{~nm}$ wavelength, output power of $40 \mathrm{~mW}$, at an energy density of $10 \mathrm{~J} / \mathrm{cm}^{2}$. The irradiation was performed daily for a maximum of 21 days. The same procedure was done in G2, but the probe was turned off. Five animals in each group were euthanized on days 7, 14 and 21 and submitted to histomorphometric analysis.

RESULTS: In both groups the growth plate was radiographically visible at all moments from both craniocaudal and mediolateral views. On the 21st day percentage of femoral longitudinal length was higher in G2 than G1 compared to basal value while hypertrophic zone chondrocyte numbers were higher in G1 than G2. Calcified cartilage zone was greater in G1 than in G2 at all evaluation moments. Angiogenesis was higher in G1 than in G2 at 14th and 21st days.
\end{abstract}

CONCLUSION: The low-level laser therapy negatively influenced the distal femoral growth plate.

Key words: Lasers. Bone Development. Chondrocytes. Laser Therapy, Low-Level. Rats.

\section{RESUMO}

OBJETIVO: Determinar a influência do Laser Terapêutico de Baixa Potência sobre a placa de crescimento de ratos.

MÉTODOS: Trinta ratos Wistar machos com 40 dias de idade foram divididos em dois grupos, G1 e G2. O grupo G1 foi submetido à irradiação com laser GaAlAs $830 \mathrm{~nm}$, potência de saída de $40 \mathrm{~mW}$, e densidade de energia de $10 \mathrm{~J} / \mathrm{cm} 2$. A irradiação foi aplicada diariamente por um período máximo de 21 dias. O mesmo procedimento foi realizado no grupo G2, com a probe desativada. Cinco animais em cada grupo foram sacrificados nos dias 7, 14 e 21 e submetidas à análise histomorfométrica.

RESULTADOS: Em ambos os grupos, o disco fisário esteve radiograficamente visível em todos os momentos nas incidências craniocaudal e médio-lateral. No $21^{\circ}$ dia a porcentagem de comprimento longitudinal do fêmur foi maior em G1 que em G2 em relação ao valor basal, e o número de condrócitos da zona hipertrófica foi maior em G1 que em G2. A zona de cartilagem calcificada estava maior em G1 em relação a G2 em todos os momentos de avaliação. A angiogênese foi maior em G1 que em G2 nos $14^{\circ}$ e $21^{\circ}$ dias.

CONCLUSÃO: A terapia com laser terapêutico de baixa potência influenciou negativamente o disco fisário distal do fêmur de ratos.

Descritores: Lasers. Desenvolvimento Ósseo. Condrócitos. Terapia a Laser de Baixa Intensidade. Ratos. 


\section{Introduction}

Low-Level Laser Therapy (LLLT) has been evaluated experimentally by in vitro and in vivo studies as well as in clinical cases $^{1}$. The mechanism that leads to a positive effect of LLLT on the tissues is not completely understood and its therapeutic role remains controversial ${ }^{1,2}$. There are some hypotheses that light energy is absorbed by intracellular chromophores, such as porphyrins and cytochromes, and converted to metabolic energy involving the respiratory chain².

The conflicting results on the effects of laser stimulation on tissues reported in some studies may be related to the great variety of treatment protocols, animal models and cellular culture models used ${ }^{1}$. In addition, the effects depend on the physiological state of the cell or tissue at the moment of exposure, the density of the applied energy as well as the wavelength and frequency of application ${ }^{3}$. LLLT has been used with positive results in promoting or accelerating the healing of tendons, ligaments, nerves, wounds, ulcers and burns, in stimulating a better healing of bone defect or bone fracture, in relieving pain of lateral epicondylitis, and in a variety of oral and dental conditions ${ }^{2-5}$, among others. However, in some cases the area to be irradiated is located next to a growth plate of a long bone in a young individual, and the risk of growth plate arrest inducing angular deformities and limb-length discrepancies by therapy stimulus should be considered ${ }^{6}$.

Therefore, the purpose of this study was to evaluate the effect of LLLT on distal femoral growth plate in immature rats using radiographic and histomorphometric analysis.

\section{Methods}

The present study was approved by the Ethics Committee from the School of Veterinary Medicine and Animal Science, UNESP at Botucatu. The use of laboratory animals followed the Council for International Organization of Medical Sciences (CIOMS) ethical code for animal experimentation and the principles of the Brazilian College on Animal Experimentation. A total of 30 healthy male Wistar rats, with average weight of $100 \mathrm{~g}$ and age of 40 days, were used. Each of six 419x366x168mm polypropylene cages housed five of the rats, who were provided water and food ad libitum. The animals were randomly divided into two groups of 15 rats each, G1 (irradiated) and G2 (control).

In G1 the lateral distal area of right femur was initially clipped to the LLLT. After this, the area of the distal femoral growth plate was irradiated at one point, using a GaAlAs diode laser with $830 \mathrm{~nm}$ wavelength and output power of $40 \mathrm{mw}$, for 20 seconds, at an energy density of $10 \mathrm{~J} / \mathrm{cm}^{2}$. The irradiation was applied daily at the same hour for 21 consecutive days. The probe was positioned perpendicular to the bone axis in direct contact with skin. In G2 the same procedure was performed, but the probe was turned off. In both groups, the rats were manipulated by manual physical containment during the treatments.

Rats were anesthetized with xylazine $(50 \mathrm{mg} / \mathrm{kg}$ body weight) and ketamine (100 mg/kg body weight), administered intramuscularly, to perform radiographic examinations. Craniocaudal and mediolateral radiographs of both femurs were obtained before LLLT, and on days 7, 14 and 21 of the treatment. Femur longitudinal length was measured from a lateral view extending from a transverse line drawn at the level of the femur head extremity to a transverse line drawn at the level of the distal edge of the condyle. In addition, the radiolucent line corresponding to distal growth plate was evaluated for the presence or absence of a radiolucent line.

In order to complete the histological analyses, five animals from each group were submitted to euthanasia at 7, 14, and 21 days of LLLT by administration of xylazine $(50 \mathrm{mg} / \mathrm{kg}$, IM) and ketamine (100 mg/kg, IM) followed by halothane. The third distal portion of each right femoral bone was collected and stored in $10 \%$ phosphate buffered formalin. The third distal portion of each right femoral bone was collected and stored in $10 \%$ phosphate buffered formalin for $24 \mathrm{~h}$. After decalcification in a $10 \%$ buffered acetic acid solution, the decalcified specimens and then they were dehydrated in alcohol, diaphanized in xylene and put into paraffin. They were then cut into $4 \mu \mathrm{m}$-width fragments and stained with Hematoxylin-Eosin (HE) and Mason's Trichrome (Figures 1, 2 and 3).

Using the stained histological sections, light microscopic histomorphometry was performed on a Leica DMR microscope (Leica Corp., UK) connected to a Leica DFC 500 color video camera and a Leica QWin Standard Version 3.1.0 image analysis software to determine the number of chondrocytes in each zone of the growth plate. For each growth plate zone a score was established based on the number of chondrocytes: (0) absent, (1) moderate (2) discreet and (3) intense (Table 1). All evaluations were performed blindly by a pathologist. 


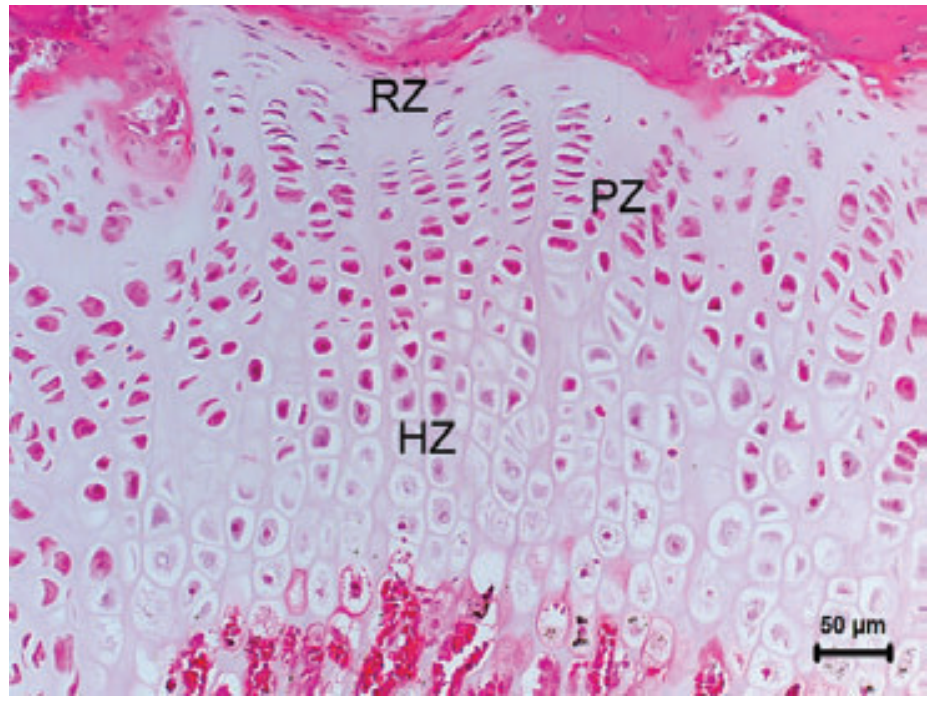

FIGURE 1 - H \& E x 200. Photomicrograph of longitudinal section of distal growth plate of the rat femur after 21 days of laser irradiation. Resting zone (RZ), Proliferative zone (PZ), Hypertrophic zone (HZ).

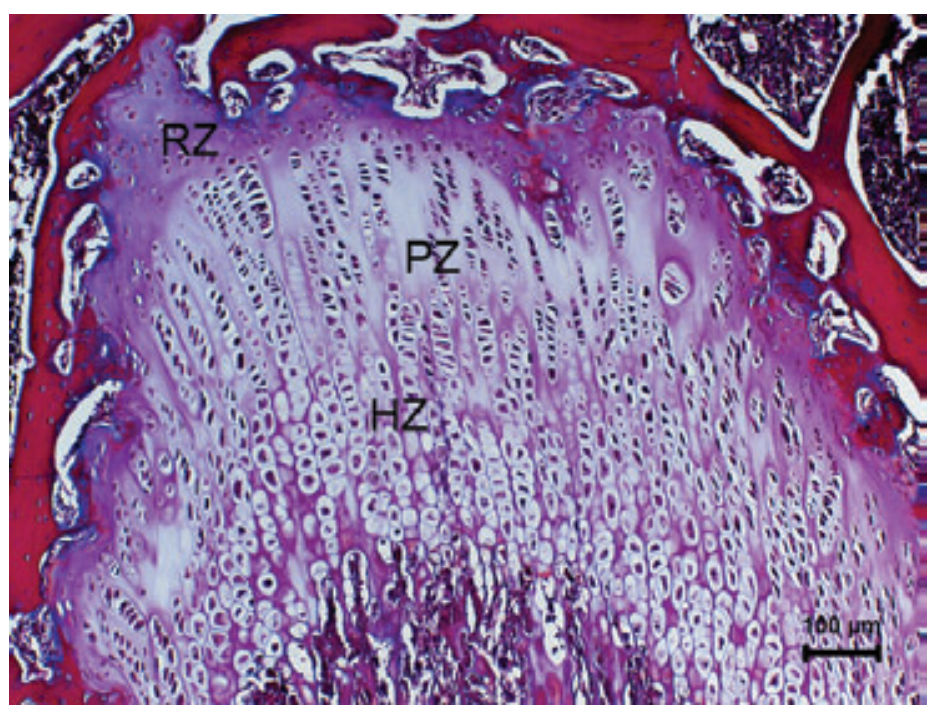

FIGURE 2 - Masson's trichrome x 200. Photomicrograph of longitudinal section of distal growth plate of the rat femur after 21 days of laser irradiation. Resting zone (RZ), Proliferative zone (PZ), Hypertrophic zone (HZ).

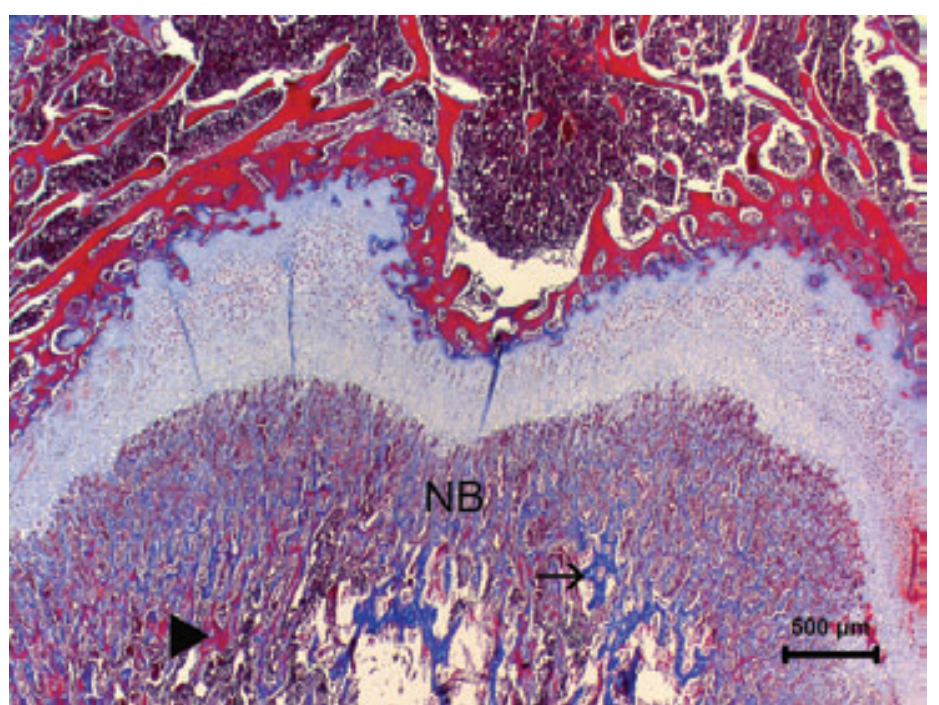

FIGURE 3 - Masson's trichrome x 25. Photomicrograph of longitudinal section of distal growth plate of the rat femur after 21 days of laser irradiation. New bone (NB), Calcified Bone Matrix (arrow head), Calcified Cartilage Matrix (arrow).

TABLE 1 - Scores based on the number of chondrocytes in resting, proliferative and hypertrophic zones.

\begin{tabular}{cccccc}
\hline \multicolumn{2}{c}{ Resting Zone } & \multicolumn{2}{c}{ Proliferative Zone } & \multicolumn{2}{c}{ Hypertrophic Zone } \\
\hline$(0)$ & absence & $(0)$ & absence & $(0)$ & absence \\
$(1)$ & $1-2$ & $(1)$ & $1-5$ & $(1)$ & $1-4$ \\
$(2)$ & $3-4$ & $(2)$ & $6-10$ & $(2)$ & $5-8$ \\
$(3)$ & $>4$ & $(3)$ & $>10$ & $(3)$ & $>8$ \\
\hline
\end{tabular}

The transition area from Calcified cartilage zone to Ossification zone was also evaluated (New bone area). Percentage distribution of osteoide deposition produced by chondrocytes and osteoblasts was performed according to properties of Masson's trichrome stain. The basophilic areas with prevalence of hyaluronic acid had green-blue staining, and acidophilic areas stained pink indicated presence of bone matrix rich in alkaline phosphatase and carbonates such as hydroxyapatite.

The procedures for angiogenesis estimations and growth plate measurements were based on criteria standardized by initial evaluation of the hematoxilin-eosin and Masson's trichome slides.

Growth plate was divided in three regions (R1, R2 and R3), each subdivided into five areas that were measured by the distance between two points perpendicular to the initial limit of the Resting Zone to the end limit of the Hypertrophic Zone. The distance between the two points was calculated by image analysis software. Five measurements per region were obtained.

The radiographic and histomorphometric data were evaluated statistically by Two-factor Analysis of Variance 
complemented by the Dunn's test. The data of growth plate size were evaluated by Two-factor Analysis of Variance with repeated measures complemented by Bonferroni multiple comparison test. Differences were considered statistically significant at $\mathrm{p}<0.05$.

\section{Results}

The growth plate was radiographically visible at all moments in both groups from both craniocaudal and mediolateral views (Figure 4). Percentage of femoral longitudinal length was higher in G1 than in G2 on day 21 compared to basal value. In G2 the percentage of longitudinal length was higher on day 21 than on day 7 (Table 2).

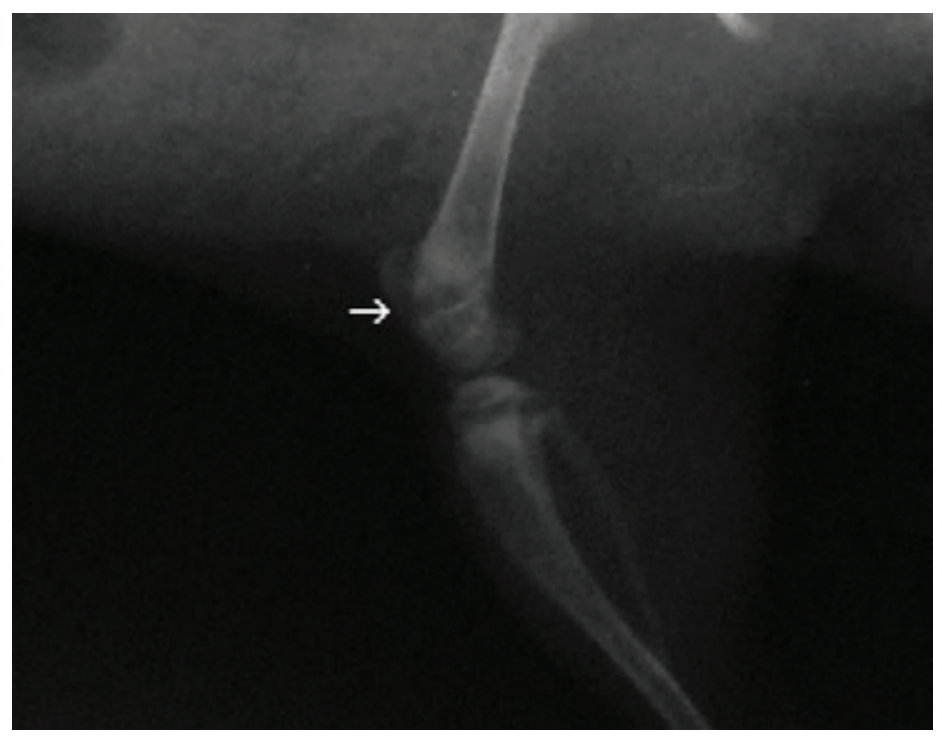

FIGURE 4 - Observe the presence of distal growth plate in a rat femur after 21 days of laser irradiation (arrow) in lateral radiographic view.

TABLE 2 - Median (minimum and maximum) values of percent variation in right femur longitudinal length in relation to the basal value, by groups (G1: irradiated, G2: control) and evaluation days.

\begin{tabular}{cccr}
\hline GROUPS & DAY 7 & DAY 14 & \multicolumn{1}{c}{ DAY 21 } \\
\hline G1 & $0.62(0.00 ; 7.76) \mathrm{aA}$ & $6.32(3.71 ; 12.01) \mathrm{aA}$ & $4,75(2.13 ; 9.64) \mathrm{aA}$ \\
G2 & $3.57(0.50 ; 9.59) \mathrm{aA}$ & $6.10(2.17 ; 13.04) \mathrm{aAB}$ & $14,41(6.86 ; 17.76) \mathrm{bB}$ \\
\hline
\end{tabular}

A,B: Means followed by different upper-case letters on the same line are statistically different

a,b: Means followed by different lower-case letters on the same column are statistically different

The chondrocyte scores observed in growth plate zones, as well as amounts of new bone, ossification zone, calcified cartilage zone and angiogenesis are described in Table 3.

Resting Zone chondrocyte numbers were diminished in both groups on day 14 compared to day 7, but there was no difference between groups. The Proliferative Zone presented no differences within or between Groups. For both groups, Resting and Hypertrophic Zone chondrocyte numbers were higher on day 7 compared to day 21. In addition, chondrocyte numbers were higher in G1 than in G2 on day 21.

The amount of new bone was higher on day 7 than on day 21 in each group, but no difference was observed between groups. No differences were found within or between groups for ossification zone. Calcified cartilage zone showed no difference in the same Group, but was higher in G1 than in G2 at all evaluation moments. On days 14 and 21 days angiogenesis was higher on day 7 in both groups and only in G2 but higher in G1 than in G2.

TABLE 3 - Median (minimum and maximum) values of the variables, according to groups (G1: irradiated, G2: control) and evaluation days.

\begin{tabular}{|c|c|c|c|c|}
\hline VARIABLES & GROUPS & DAY 7 & DAY 14 & DAY 21 \\
\hline \multirow{2}{*}{ Resting Zone } & G1 & $3.0(2.0 ; 3.0) \mathrm{aB}$ & $2.0(1.0 ; 2.0) \mathrm{aA}$ & $2.0(1.0 ; 2.0) \mathrm{aA}$ \\
\hline & G2 & $2.0(2.0 ; 2.0) \mathrm{aB}$ & $1.0(1.0 ; 2.0) \mathrm{aA}$ & $1.0(1.0 ; 2.0) \mathrm{aA}$ \\
\hline \multirow{2}{*}{ Proliferative Zone } & G1 & $3.0(3.0 ; 3.0) \mathrm{aA}$ & $2.0(2.0 ; 3.0) \mathrm{aA}$ & $3.0(2.0 ; 3.0) \mathrm{aA}$ \\
\hline & G2 & $3.0(2.0 ; 3.0) \mathrm{aA}$ & $3.0(2.0 ; 3.0) \mathrm{aA}$ & $3.0(2.0 ; 3.0) \mathrm{aA}$ \\
\hline \multirow{2}{*}{ Hypertrophic Zone } & G1 & $3.0(2.0 ; 3.0) \mathrm{aB}$ & $2.0(1.0 ; 3.0) \mathrm{aAB}$ & $2.0(2.0 ; 2.0) \mathrm{bA}$ \\
\hline & G2 & $2.0(2.0 ; 3.0) \mathrm{aB}$ & $2.0(2.0 ; 2.0) \mathrm{aAB}$ & $1.0(1.0 ; 2.0) \mathrm{aA}$ \\
\hline \multirow{2}{*}{ New bone area } & G1 & $3.0(3.0 ; 3.0) \mathrm{aB}$ & $3.0(2.0 ; 3.0)$ aAB & $2.0(2.0 ; 3.0) \mathrm{aA}$ \\
\hline & G2 & $3.0(2.0 ; 3.0) \mathrm{aB}$ & $2.0(1.0 ; 3.0)$ aAB & $2.0(1.0 ; 2.0) \mathrm{aA}$ \\
\hline \multirow{2}{*}{$\begin{array}{c}\text { Calcified cartilage } \\
\text { Zone }\end{array}$} & G1 & $3.0(1.0 ; 3.0) \mathrm{bA}$ & $3.0(3.0 ; 3.0) \mathrm{bA}$ & $3.0(3.0 ; 3.0) \mathrm{bA}$ \\
\hline & G2 & $1.0(1.0 ; 3.0) \mathrm{aA}$ & $1.0(1.0 ; 1.0) \mathrm{aA}$ & $1.0(1.0 ; 1.0) \mathrm{aA}$ \\
\hline \multirow{2}{*}{ Ossification Zone } & G1 & $2.0(1.0 ; 3.0) \mathrm{aA}$ & $2.0(2.0 ; 3.0) \mathrm{aA}$ & $2.0(1.0 ; 3.0) \mathrm{aA}$ \\
\hline & G2 & $3.0(2.0 ; 3.0) \mathrm{aA}$ & $3.0(2.0 ; 3.0) \mathrm{aA}$ & $2.0(2.0 ; 3.0) \mathrm{aA}$ \\
\hline \multirow{2}{*}{ Angiogenesis } & G1 & $3.0(3.0 ; 3.0) \mathrm{aA}$ & $3.0(3.0 ; 3.0) \mathrm{bA}$ & $3.0(2.0 ; 3.0) \mathrm{bA}$ \\
\hline & G2 & $3.0(3.0 ; 3.0) \mathrm{aB}$ & $2.0(2.0 ; 3.0) \mathrm{aA}$ & $2.0(2.0 ; 3.0) \mathrm{aA}$ \\
\hline
\end{tabular}

A,B: Means followed by different upper-case letters on the same line are statistically different

a,b: Means followed by different lower-case letters on the same column are statistically different

The measurements of growth plate (Table 4) showed no difference within or between groups in region R1. In region R2 only G2 presented size diminishment from the 14th to 21st day. G1 not only surpassed G2 on day 7 but also showed elevation in R3 from day 7 to day 21.

Comparing all regions (Table 4), G1 showed no difference in measurements at all evaluation moments. Among G2 rats, regions $\mathrm{R} 1$ and $\mathrm{R} 2$ were larger than region $\mathrm{R} 3$ on the 7th day. The $\mathrm{R} 2$ region was greater than region $\mathrm{R} 1$ and $\mathrm{R} 3$ on day 14 , but 
no difference occurred on day 21.

TABLE 4 - Mean values $( \pm S D)$ of the measurements (mm) of the growth plate, by groups (G1: irradiated, G2: control) and evaluation days.

\begin{tabular}{ccccc}
\hline Regions Groups & Day 7 & Day 14 & Day 21 \\
& & & & \\
\hline \multirow{2}{*}{ R1 } & $\mathrm{G} 1$ & $0.569 \pm 0.081 \mathrm{aA} \square$ & $0.503 \pm 0.218 \mathrm{aA} \square$ & $0.344 \pm 0.126 \mathrm{aA} \square$ \\
& $\mathrm{G} 2$ & $0.531 \pm 0.291 \mathrm{aA} \square$ & $0.443 \pm 0.031 \mathrm{aA} \square$ & $0.303 \pm 0.091 \mathrm{aA} \square$ \\
& $\mathrm{G} 1$ & $0.487 \pm 0.132 \mathrm{aA} \square$ & $0.497 \pm 0.053 \mathrm{aA} \square$ & $0.378 \pm 0.113 \mathrm{aA} \square$ \\
R2 & $\mathrm{G} 2$ & $0.509 \pm 0.087 \mathrm{aB} \square$ & $0.542 \pm 0.151 \mathrm{aB} \square$ & $0.330 \pm 0.096 \mathrm{aA} \square$ \\
& $\mathrm{G} 1$ & $0.513 \pm 0.081 \mathrm{bB} \square$ & $0.442 \pm 0.108 \mathrm{aAB} \square$ & $0.352 \pm 0.074 \mathrm{aA} \square$ \\
R3 & $\mathrm{G} 2$ & $0.361 \pm 0.055 \mathrm{aA} \square$ & $0.459 \pm 0.11 \mathrm{aA} \square$ & $0.330 \pm 0.103 \mathrm{aA} \square$ \\
\hline
\end{tabular}

A,B: Means followed by different upper-case letters on the same line are statistically different

a,b: Means followed by different lower-case letters on the same column are statistically different

$\square \square$ : Means followed by different lower-case letters on the same column are statistically different among R1, R2 and R3.

\section{Discussion}

The positive effects of LLLT in different tissues found here in corroborate earlier findings utilizing helium-neon ${ }^{5}$, gallium-arsenide ${ }^{7}$, and gallium-aluminum-arsenide ${ }^{4}$. In the present study a gallium-aluminum-arsenide laser was used due to its continuous emission and emission time for each Joule of / per 2 seconds. Equipments with wavelengths up to $900 \mathrm{~nm}$ need more than 20 seconds to obtain the same amount of energy ${ }^{8}$. In general, LLLT is characterized by wavelengths of $632.8 \mathrm{~nm}, 820 \mathrm{~nm}, 830$ $\mathrm{nm}$ or $904 \mathrm{~nm}$ with irradiation of $1-4 \mathrm{~J} / \mathrm{cm}^{2}$ for up to 30s on daily or alternate-day doses ${ }^{3,9,10}$. The present study employed $830 \mathrm{~nm}$ wavelength, output power of $40 \mathrm{~mW}$, for 20 seconds, at an energy density of $10 \mathrm{~J} / \mathrm{cm}^{2}$ because the same wavelength and dose have been used for bone healing or reducing pain of temporomandibular joint disorders ${ }^{11,12}$.

In rats, the growth plate remains present in aged rats despite the absence of longitudinal growth ${ }^{13}$. For this reason the growth plate was radiographically visible at all moments in both groups from both craniocaudal and mediolateral views. On the other hand, differences in the bone length on day 21 were observed especially in G1 as compared to G2, suggesting a negative effect of LLLT on growth plate proportional to the number of irradiation days. In addition, the rats were approximately 6 weeks of age on the first day of irradiation, a transitional period between a phase of accelerating growth (up to 5 weeks) and a time of decelerating growth (8-16 weeks) ${ }^{13}$, indicating that irradiation action occurs despite the longitudinal length rate of the bone.

Laser irradiation is able to modify the cellular processes in a wavelength-dependent manner that is almost non-thermal ${ }^{2,3}$. Lasers with output power between 10 and $90 \mathrm{~mW}$, as used in the study, promote temperature elevation in the irradiated tissues on the order of 0.5 to $0.75^{\circ} \mathrm{C}$ and do not induce deleterious effect on account of the small area in which their intensity is focused ${ }^{3}$. Thus, the temperature probably did not influence the growth plate.

In general, a close relationship exists between light parameters and biostimulation on the cellular level, and between irradiation moment and magnitude limits of biostimulation effects. Thus, the low-level irradiation may inhibit as well as stimulate the cellular activity ${ }^{3}$. This is corroborated by the increased angiogenesis observed in G1 on the 14th and 21st days and by the larger calcified cartilage zone at all evaluation moments as compared to G2. On the other hand, the chondrocyte numbers in the hypertrophic zone were higher in G1 than in G2 on day 21.

Although the positive mechanisms of LLLT are not completely understood ${ }^{2,3}$, the following effects may be cited: stimulus of cell growth, cell regeneration and increased cellular activity, increased revascularization, anti-inflammatory and analgesic effects, among others ${ }^{1,3,14}$. This may explain the fact that angiogenesis presented a greater magnitude in G1 than G2. On the other hand, this elevated angiogenesis may have contributed to early chondrocyte death and formation of calcified cartilage, contributing to reduction of the femoral longitudinal length. In addition, although chondrocyte numbers in the Hypertrophic Zone had increased in the irradiated group on day 21, apparently this was not sufficient to influence the total length of the limb.

On the other hand, in a study using an 830-nm galliumaluminum-arsenide diode laser at two different energy densities (5 and $15 \mathrm{~J} / \mathrm{cm}^{2}$ ) on the tibial growth plate of 23-day-old rats, histometric analysis revealed a reduction in the thickness of the resting and hypertrophic zones, and a rise in the number of chondrocytes in the degenerative zone, but without changes in total bone length ${ }^{6}$. In another study, irradiation of the rat mandible growth center ( $\square=904 \mathrm{~nm}, 2000 \mathrm{~Hz}$, pulse length $200 \mathrm{~ns}$ and output power $4 \mathrm{~mW}$ ) on days $0,2,4,6,8$ and 10, with the protocol repeated after a 50 -day interval, produced higher growth than that observed in controls ${ }^{15}$. In both studies the type of bone irradiated, and the total dose, points and intervals of irradiation, among other factors, may have contributed to the differences in results. 


\section{Conclusion}

The GaAlAs therapy as used in our study had a negative influence on the distal femoral growth plate in rats, as shown by radiographic and histomorphometric analyses.

\section{References}

1. Bjordal JM, Johnson MI, Iversen V, Aimbire F, Lopes-Martins RAB. Low-level laser therapy in acute pain: a systematic review of possible mechanisms of action and clinical effects in randomized placebo-controlled trials. Photomed Laser Surg. 2006;24(2):158-68.

2. Pinheiro ALB, Gerbi MEMM. Photoengineering of bone repair processes. Photomed Laser Surg. 2006;24(2):169-78.

3. Hawkins D, Abrahamse H. Laboratory methods for evaluating the effect of low level laser therapy (LLLT) in wound healing. Afr J Biomed Res. 2005;(8):1-14.

4. Miloro M, Halkias LE, Mallery S, Travers S, Rashid RG. Low-level laser effect on neural regeneration in Gore-tex tubes. Oral Surg Oral Med Oral Pathol Oral Radiol Endod. 2002;93(1):27-34.

5. Reddy GK, Stehno-Bittel L, Enwemeka CS. Laser photostimulation of collagen production in healing rabbit Achilles tendons. Lasers Surg Med. 1998;22(5):281-7.

6. Cressoni MDC, Giusti HHKD, Pião AC, Carvalho RLPC, Anaruma CA, Casarotto RAC. Effect of GaAIAs laser irradiation on the epiphyseal cartilage of rats. Photomed Laser Surg. 2010;28(4):52732.

7. Demir H, Menku P, Kirnap M, Calis M, Ikizceli I. Comparison of the effects of laser, ultrasound, and combined laser + ultrasound treatments in experimental tendon healing. Lasers Surg Med. 2004;35(1):84-9.

8. Bioset. http://www.bioset.com.br. Acessed 28 May 2010.

9. Renno ACM, Moura FM, Santos NSA, Tirico RP, Bossini PS, Parizzotto NA. Effects of 830-nm laser light on preventing bone loss after ovariectomy. Photomed Laser Surg. 2006;24(5):642-5.

10. Stein A, Benayahu D, Maltz L, Oron U. Low-level laser irradiation promotes proliferation and differenciation of human osteoblasts in vitro. Photomed Laser Surg. 2005;23(2):161-6.

11. Liu X, Lyon R, Meier HT, Thometz J, Haworth ST. Effect of lowerlevel laser therapy on rabbit tibial fracture. Photomed Laser Surg. 2007;25(6):487-94.

12. Weber JBB, Pinheiro ALB, Oliveira MG, Oliveira FAM, Ramalhol MP. Laser therapy improves healing of bone defects submitted to autologus bone graft. Photomed Laser Surg. 2006;24(1):38-44.

13. Roach HI, Mehta G, Oreffo ROC, Clark NMP, Cooper C. Temporal analysis of rat growth plates: cessation of growth with age despite presence of a physis. J Histochem Cytochem. 2003;52(3):373-83.

14. Matsumoto MA, Ferrino RV, Monteleone GF, Ribeiro DA. LowLevel Laser therapy modulates cyclo-oxygenase-2 expression during bone repair in rats. Lasers Med Sci. 2008;24(2):195-201.

15. Seifi M, Maghzi A, Gutknecht N, Mir M, Asna-Ashari M. The effect of $904 \mathrm{~nm}$ low level laser on condylar growth in rats. Lasers Med Sci. 2010;25(1):61-5.

\section{Correspondence:}

Sidney Piesco de Oliveira

Departamento Cirurgia Veterinária e Anestesiologia

Escola de Medicina Veterinária e Ciência Animal

Universidade Estadual Paulista

Distrito de Rubião Jr, s/n

18618-970 Botucatu - SP Brasil

Te.: (55 14)3811-6054

sidney@ibravet.com.br

Received: September 20, 2011

Review: November 22, 2011

Accepted: December 19, 2011

Conflict of interest: none

Financial source: none

${ }^{1}$ Research performed at School of Veterinary Medicine and Animal Science, State Paulista University (UNESP), Botucatu-SP, Brazil - Part of Master degree thesis. Mentor: Sheila Canevese Rahal. 